\title{
PENGARUH KUALITAS PELAYANAN DAN KUALITAS PRODUK TERHADAP KEPUASAN PELANGGAN PERUSAHAAN PEMBIAYAAN (LEASING) STUDI KASUS PT. BCA FINANCE KANTOR PUSAT PONDOK INDAH
}

\author{
Ratih Andalusi', Ahmad Maulana Irfanudin ${ }^{2}$ \\ Fakultas Ekonomi, Universitas Pamulang \\ Email: dosen01854@unpam.ac.id ${ }^{1}$; dosen01868@unpam.ac.id ${ }^{2}$
}

\begin{abstract}
Purpose. This study aims to testing and analyzing Service Quality and Product Quality that affect Customer Satisfaction at PT.BCA Finance Head Office.

Methods. This research method is carried out through an associative approach with quantitative descriptive methods. Data analysis used regression analysis, correlation coefficient analysis, determination coefficient analysis, and hypothesis testing. The sampling method used was the Purpose Random Sampling Technique, namely consumers who made transactions with PT. BCA Finance, Head Office for the last 3 months, with a total of 130 respondents. The analysis technique used is the quality of validity and reliability, and class assumptions, namely the normal and autocorrelation test, as well as the linear regression test, the coefficient of determination, and the hypothesis test with SPSS application processing.
\end{abstract}

Findings. The results of this research show that there is a positive and significant influence between service quality and product quality on customer satisfaction partially and simultaneously, with the equation multiple linear regression $Y=44.440+0.437 X 1+0.350 X 2$. Adjust R-Square value of 0.420 which indicates the quality of service and products to customer satisfaction contributes $42.0 \%$, the simultaneous $F$ test of service quality and product quality is 23.335> 2,680 with a sig value of 0,000<0.1, reflecting a significant influence.

Implication. To improve customer satisfaction, the company should always promote good customer service and good quality products to its customers, by providing standardized services company and provides a straightforward and clear explanation regarding financial products that give a good impression as well as improved customer satisfaction.

Keywords: Service Quality, Products, Leasing

\begin{abstract}
ABSTRAK
Tujuan. Penelitian ini ditujukan menguji dan menganalisis Kualitas Pelayanan dan Kualitas Produk berpengaruh terhadap Kepuasan Pelanggan PT. BCA Finance Kantor Pusat.

Metode. Metode penelitian ini dilakukan melalui pendekatan assosiatif dengan metode deskriptif kuantitatif. Analisis data menggunakan analisis regresi, analisis koefisien korelasi, analisis koefisien determinasi dan uji hipotesis. Metode pengambilan sampel dengan Teknik Purpose Random Sampling, yakni konsumen yang melakukan transaksi dengan PT. BCA Finance, Kantor Pusat selama 3 bulan terakhir, dengan keseluruhan 130 responden. Teknik Analisis yang dilakukan yaitu kualitas diataranya validitas dan
\end{abstract}


reliabilitas, dan asumsi klasik yaitu uji normalitas dan autokorelasi, serta uji regresi linier, koefisien determinasi, dan uji hipotesis dengan pengolahan aplikasi SPSS.

Hasil. Hasil penelitiaan menunjukkan terdapat pengaruh positif dan signifikan antara kualitas layanan, dan kualitas produk terhadap Kpuasan pelanggan secara parsial maupun simultan, dengan persamaaan regresi linier berganda $Y=44,440+0,437 \mathrm{X} 1+0,350 \mathrm{X} 2$. Nilai Adjust R-Square snilai 0,420 yang mengindikasikan kualitas pelayanan dan produk tehadap Kpuasan Pelanggan memberikan kontribusi sebesar $42.0 \%$, Uji simultan $\mathrm{F}$ kualitas Pelayanan dan kual produk sebesar 23,335> 2,680 dengan nilai sig 0,000<0,1, mencerminkan terdapat pengaruh yang signifikan.

Implikasi. Untuk meningkatkan kepuasan pelanggannya, sebaiknya perusahaan selalu mengedepankan pelayanan yang prima serta kualitas produk yang baik kepada para nasabahnya, dengan cara memberikan pelayanan sesuai standar perusahaan serta memberikan penjelasan secara lugas dan jelas mengenai produk pembiayaan sehingga memberikan kesan yang baik serta kepuasan pelanggan yang meningkat.

Kata Kunci. Kualitas Pelayanan, Produk, Pembiayaan

\section{Pendahuluan}

Dewasa ini, kebutuhan masyarakat semakin hari semakin meningkat, terutama kebutuhan akan kendaraan baik motor maupun mobil. Perekonomian yang kurang stabil membuat banyak pihak menawarkan solusi untuk membantu kebutuhan masyarakat akan kebutuhan alat transportasi. Maka dari itu pembelian kendaraan dengan sistem kredit melalui jasa lembaga pembiayaan merupakan salah satu alternatif yang dipilih oleh nasabah untuk mendapatkan jenis kendaraan yang mereka kehendaki melalui beberapa prosedur beserta harga angsuran berdasarkan jangka waktu dan suku bunga yang telah ditentukan oleh pihak perusahaan.

Perusahaan atau lembaga pembiayaan adalah badan usaha di luar bank atau lembaga keuangan bukan bank lainnya yang memberikan fasilitas pinjaman kepada nasabahnya untuk suatu keperluan. Sama seperti bank dan lembaga resmi lainnya, mekanisme mengenai perusahaan pembiayaan telah diketahui negara dan sudah diatur pula dalam peraturan Menteri Keuangan Nomor 84/PMK.012/2006 tentang Perusahaan Pembiayaan. Pada umumnya, lembaga keuangan seperti bank akan memberikan dana cair kepada para calon debiturnya.

Ketika seorang nasabah mengajukan kredit ke lembaga pembiayaan untuk keperluan pembelian barang, nasabah akan mendapatkan dana cair tersebut setelah mendapatkan persetujuan dari perusahaan tempat nya melakukan transaksi perdagangan. Dengan kata lain, dana tunai dibayarkan perusahaan pembiayaan kepada pihak ketiga, tempat nasabah melakukan transaksi pembelian. Dengan hadirnya perusahaan pembiayaan, masalah keterbatasan dana untuk membeli barang-barang telah terpecahkan. Nasabah bisa menggunakan layanan dari perusahaan pembiayaan untuk pembelian barang dengan cara mengangsur atau mencicil.

Kepuasan yang dirasakan oleh nasabah untuk melakukan kredit pembiayaan menjadi hal yang krusial dan tidak dapat dipungkiri bagi suatu lembaga pembiayaan. Akan tetapi, pada realitasnya, sistem pelayanan kredit bagi nasabah tidak didukung oleh kualitas pelayanan dan kualitas produk yang memadai. Hal ini terjadi pada salah satu lembaga pembiayaan (leasing) terbesar di Indonesia, yaitu PT. BCA Finance yang memiliki Kantor Pusat di Wisma Pondok Indah. BCA Finance merupakan pihak representatif leasing yang cukup besar, yang saat ini sedang berkembang pesat baik dari segi jumlah nasabah ataupun assetnya. Dalam bidang pembiayaan, sampai dengan saat ini, perusahaan tersebut masih tetap fokus di sektor pembiayaan mobil. Akan tetapi, seperti yang telah disebutkan sebelumnya, sistem pelayanan kredit bagi nasabah tersebut tidak didukung oleh kualitas pelayanan dan kualitas produk yang berdampak pada tingkat kepuasan pelanggan. 
Tabel 1 Standar Pelayanan

\begin{tabular}{|c|l|l|l|}
\hline No. & \multicolumn{1}{|c|}{ Strandar Pelayanan } & \multicolumn{1}{|c|}{ Realita } & \multicolumn{1}{c|}{ Keterangan } \\
\hline 1 & $\begin{array}{l}\text { Layanan pengurusan } \\
\text { pengajuan kredit 3 hari. }\end{array}$ & $\begin{array}{l}\text { Lebih dari 3 hari } \\
\text { proses persetujuan. }\end{array}$ & $\begin{array}{l}\text { Sering terjadi terhadap konsumen } \\
\text { tidak memiliki rumah. }\end{array}$ \\
\hline 2 & $\begin{array}{l}\text { Ketentuan pinalti lewat } \\
\text { 30 hari kerja. }\end{array}$ & $\begin{array}{l}\text { Kurang dari 30 hari } \\
\text { sudah ada surat } \\
\text { pinalti. }\end{array}$ & $\begin{array}{l}\text { Banyak konsumen merasa } \\
\text { dirugikan karena tidak sesuai } \\
\text { standard pelayanan. }\end{array}$ \\
\hline
\end{tabular}

Sumber : PT BCA Finance, 2020

Kurangnya dukungan kualitas pelayanan dan kualitas produk akan berdampak pada penurunan tingkat kepuasan pelanggan sehingga penjualan aset kredit suatu lembaga pembiayaan akan menurun. PT. BCA Finance memperlihatkan hal tersebut melalui kenaikan dan penurunan asset penjualannya selama 5 (lima) tahun terakhir. Untuk lebih jelasnya, dapat di lihat pada tabel berikut ini :

Tabel 2 Data Penjualan PT. BCA Finance Dari Tahun 2015-2019

\begin{tabular}{|c|c|c|}
\hline Tahun & Target & Pencapaian \\
\hline 2015 & $\operatorname{Rp~700.000.000.000~}$ & $\operatorname{Rp~732.555.538.192~}$ \\
\hline 2016 & $\operatorname{Rp~750.000.000.000}$ & $\operatorname{Rp~683.055.932.336~}$ \\
\hline 2017 & $\operatorname{Rp~} 800.000 .000 .000$ & $\operatorname{Rp~747.805.938.485~}$ \\
\hline 2018 & $\operatorname{Rp~} 850.000 .000 .000$ & $\operatorname{Rp} 628.111 .192 .384$ \\
\hline 2019 & $\operatorname{Rp~} 900.000 .000 .000$ & $\operatorname{Rp} 565.583 .830 .829$ \\
\hline
\end{tabular}

Sumber: PT.BCA Finance, 2020

Dengan demikian, untuk memberikan kepuasan kepada nasabah, PT. BCA Finance harus memiliki sistem pelayanan kredit yang didukung oleh kualitas pelayanan dan kualitas produk yang memadai. Dengan demikian, hal-hal tersebut akan berdampak baik pada peningkatan penjualan aset kredit PT. BCA Finance.

Berdasarkan latar belakang masalah tersebut maka penulis tertarik memberikan judul penelitian "PENGARUH KUALITAS PELAYANAN DAN KUALITAS PRODUK TERHADAP KEPUASAN PELANGGAN PADA PERUSAHAAN PEMBIAYAAN (LEASING) (STUDI KASUS PADA PT. BCA FINANCE KANTOR PUSAT PONDOK INDAH)".

\section{Kajian Pustaka dan Hipotesis}

Kualitas Pelayanan. "Kualitas pelayanan merupakan faktor dan akar penting yang mampu memberikan kepuasan bagi pelanggannya. Sehingga pelanggan merasa puas dengan pelayanan yang diberikan". Menurut Fandy Tjiptono (2007), kualitas pelayanan adalah upaya pemenuhan kebutuhan dan keinginan konsumen serta ketepatan penyampaiannya dalam mengimbangi harapan konsumen. Sementara itu, menurut Philip Kotler (2002:83) kualitas pelayanan adalah setiap tindakan atau kegiatan yang dapat ditawarkan oleh suatu pihak kepada pihak lain, yang pada dasarnya tidak berwujud dan tidak mengakibatkan kepemilikan apapun.

Kriteria Kualitas Pelayanan. Fandy Tjiptono menegaskan, dalam kualitas pelayanan yang baik, terdapat beberapa jenis kriteria pelayanan (Tjiptono, 2007), antara lain adalah sebagai berikut:

a. Ketepatan waktu pelayanan, termasuk didalamnya waktu untuk menunggu selama transaksi maupun proses pembayaran.

b. Akurasi pelayanan, yaitu meminimalkan kesalahan dalam pelayanan maupun transaksi.

c. Sopan santun dan keramahan ketika memberikan pelayanan.

d. Kemudahan mendapatkan pelayanan, yaitu seperti tersedianya sumber daya manusia untuk membantu melayani konsumen, serta fasilitas pendukung seperti komputer untuk mencari ketersediaan suatu produk. 
e. Kenyaman konsumen, yaitu seperti lokasi, tempat parkir, ruang tunggu yang nyaman, aspek kebersihan, ketersediaan informasi, dan lain sebagainya.

Kualitas Produk. "Kualitas produk merupakan salah satu faktor yang mempengaruhi kepuasan konsumen. Kualitas produk ditentukan oleh sekumpulan kegunaan dan fungsinya, termasuk kinerja/ performance, daya tahan, kesesuaian dengan spesifikasi, estetika produk, dan juga perceived quality/ kesan produk". Menurut Kotler dan Armstrong (2012), kualitas produk adalah kemampuan sebuah produk dalam memperagakan fungsinya, hal ini termasuk keseluruhan durabilitas, reliabilitas, ketepatan, kemudahan pengoperasian, dan reparasi produk, juga atribut produk lainnya. Menurut Nasution (2005), kualitas produk adalah suatu kondisi dinamis yang berhubungan dengan produk, manusia/tenaga kerja, proses dan tugas, serta lingkungan yang memenuhi atau melebihi harapan konsumen. Menurut Tjiptono (2012), kualitas produk adalah tingkat mutu yang diharapkan dan pengendalian keragaman dalam mencapai mutu tersebut untuk memenuhi kebutuhan konsumen.

Menurut Prawirosentono (2002), kualitas produk adalah keadaan fisik, fungsi dan sifat suatu produk bersangkutan yang dapat memenuhi selera dan kebutuhan konsumen dengan memuaskan sesuai nilai uang yang dikeluarkan. Menurut Kotler dan Keller (2012), kualitas produk adalah kemampuan suatu barang untuk memberikan hasil atau kinerja yang sesuai bahkan melebihi dari apa yang diinginkan pelanggan. Mewujudkan kualitas yang dirasakan penting. Persaingan yang saat ini bukan lagi masalah harga melainkan kualitas produk, hal inilah yang mendorong konsumen untuk mau membeli produk dengan harga tinggi namun dengan kualitas yang tinggi pula.

Tingkatan Kualitas Produk. Menurut Arif (2012), terdapat lima tingkatan dalam kualitas produk, yaitu:

a. Manfaat inti (Core Benefit). Yaitu jasa atau manfaat inti sesungguhnya yang dibeli dan diperoleh oleh konsumen. Kebutuhan konsumen paling fundamental adalah manfaat, dan ini merupakan tingkatan paling fundamental dari suatu produk. Seorang pemasar harus mampu melihat dirinya sebagai seseorang yang menyediakan manfaat kepada konsumen. Sehingga konsumen pun pada akhirnya akan membeli produk tersebut karena manfaat inti yang terdapat didalamnya.

b. Manfaat dasar tambahan (Basic Product). Tingkat selanjutnya seorang pemasar harus mampu merubah manfaat inti menjadi produk dasar. Pada inti produk tersebut terdapat manfaat bentuk dasar produk atau mampu memenuhi fungsi dasar produk kebutuhan konsumen adalah fungsional.

c. Harapan produk (Expected Product). Adalah serangkaian kondisi yang diharapkan dan disenangi, dimiliki atribut produk tersebut. Kebutuhan konsumen adalah kelayakan. Misalnya dalam jasa perhotelan harapan konsumen adalah kenyamanan untuk beristirahat dan menghilangkan kepenatan atas segala aktivitas yang telah dilakukannya.

d. Kelebihan yang dimiliki produk (Augmented Product). Yaitu salah satu manfaat dan pelayanan yang dapat membedakan produk tersebut dengan pesaing. Kebutuhan konsumen adalah kepuasan. Misalnya di perbankan disediakan suatu produk tabungan berencana, dimana di dalam produk tersebut nasabah dapat menyimpan dan menginvestasikan dananya sekaligus mendapatkan jaminan asuransi jiwa dan kesehatan dengan membayar sejumlah premi tambahan tertentu. Kelebihan tawaran produk tersebut yang dicari oleh nasabah.

e. Potensi masa depan produk (Potensial Product). Artinya bagaimana harapan masa depan dengan produk tersebut apabila terjadi perubahan dan perkembangan teknologi serta selera konsumen. Kebutuhan konsumen adalah masa depan produk. Misalnya kemudahan untuk membayar tagihan telepon, listrik, air atau tagihan lainnya.

Kepuasan Pelanggan. Kepuasan pelanggan adalah tingkat perasaan konsumen setelah membandingkan antara apa yang dia terima dan harapannya (Umar, 2005:65). Seorang pelanggan, jika merasa puas dengan nilai yang diberikan oleh produk atau jasa, sangat besar 
kemungkinannya menjadi pelanggan dalam waktu yang lama. Menurut Philip Kotler dan Kevin Lane Keller yang dikutip dari buku Manajemen Pemasaran mengatakan bahwa kepuasan pelanggan adalah perasaan senang atau kecewa seseorang yang muncul setelah membandingkan kinerja (hasil) produk yang dipikirkan terhadap kinerja yang diharapkan (2007:177). Menurut Kotler dan Armstrong, Kepuasan konsumen adalah sejauh mana anggapan kinerja produk memenuhi harapan pembeli. Bila kinerja produk lebih rendah ketimbang harapan pelanggan, maka pembelinya merasa puas atau amat gembira.

Faktor Penentu Kepuasan Pelanggan. Faktor-faktor yang mempengaruhi persepsi dan harapan pelanggan menurut Gaspersz dalam (Nasution, 2005: 50) adalah sebagai berikut:

a. Kebutuhan dan keinginan yang berkaitan dengan hal-hal yang dirasakan pelanggan ketika ia sedang mencoba melakukan transaksi dengan produsen/pemasok produk (perusahaan). Jika pada saat itu kebutuhan dan keinginannya besar, harapan atau ekspektasi pelanggan akan tinggi, demikian pula sebaliknya.

b. Pengalaman masa lalu ketika mengkonsumsi produk dari perusahaan maupun pesaingpesaingnya.

c. Pengalaman dari teman-teman, dimana mereka akan menceritakan kualitas produk yang akan dibeli oleh pelanggan itu. Hal ini jelas mempengaruhi persepsi pelanggan terutama pada produk-produk yang dirasakan berisiko tinggi.

d. Komunikasi melalui iklan dan pemasaran juga mempengaruhi persepsi pelanggan. Orangorang di bagian penjualan dan periklanan seyogianya tidak membuat kampanye yang berlebihan melewati tingkat ekspektasi pelanggan.

Metode Pengukuran Kepuasan Pelanggan. Menurut Kotler yang dikutip dari Buku Total Quality Management ada beberapa metode yang dapat digunakan dalam melakukan pengukuran kepuasan pelanggan, diantaranya (Tjiptono, 2003:104):

a. Sistem keluhan dan saran

Organisasi yang berpusat pelanggan (Customer Centered) memberikan kesempatan yang luas kepada para pelanggannya untuk menyampaikan saran dan keluhan. Informasiinformasi ini dapat memberikan ide-ide cemerlang bagi perusahaan dan memungkinkannya untuk bereaksi secara tanggap dan cepat untuk mengatasi masalahmasalah yang timbul.

b. Ghost shopping

Salah satu cara untuk memperoleh gambaran mengenai kepuasan pelanggan adalah dengan mempekerjakan beberapa orang untuk berperan atau bersikap sebagai pembeli potensial, kemudian melaporkan temuan-temuannya mengenai kekuatan dan kelemahan produk perusahaan dan pesaing berdasarkan pengalaman mereka dalam pembelian produkproduk tersebut. Selain itu para ghot shopper juga dapat mengamati cara penanganan setiap keluhan.

c. Lost customer analysis

Perusahaan seyogyanya menghubungi para pelanggan yang telah berhenti membeli atau yang telah pindah pemasok agar dapat memahami mengapa hal itu terjadi. Bukan hanya exit interview saja yang perlu, tetapi pemantauan customer loss rate juga penting, peningkatan customer loss rate menunjukkan kegagalan perusahaan dalam memuaskan pelanggannya.

d. Survey kepuasan pelanggan

Umumnya penelitian mengenai kepuasan pelanggan dilakukan dengan penelitian survvey, baik melalui pos, telepon, maupun wawancara langsung. Perusahaan akan memperoleh tanggapan dan umpan balik secara langsung dari pelanggan dan juga memberikan tanda (signal) positif bahwa perusahaan menaruh perhatian terhadap para pelanggannya. 


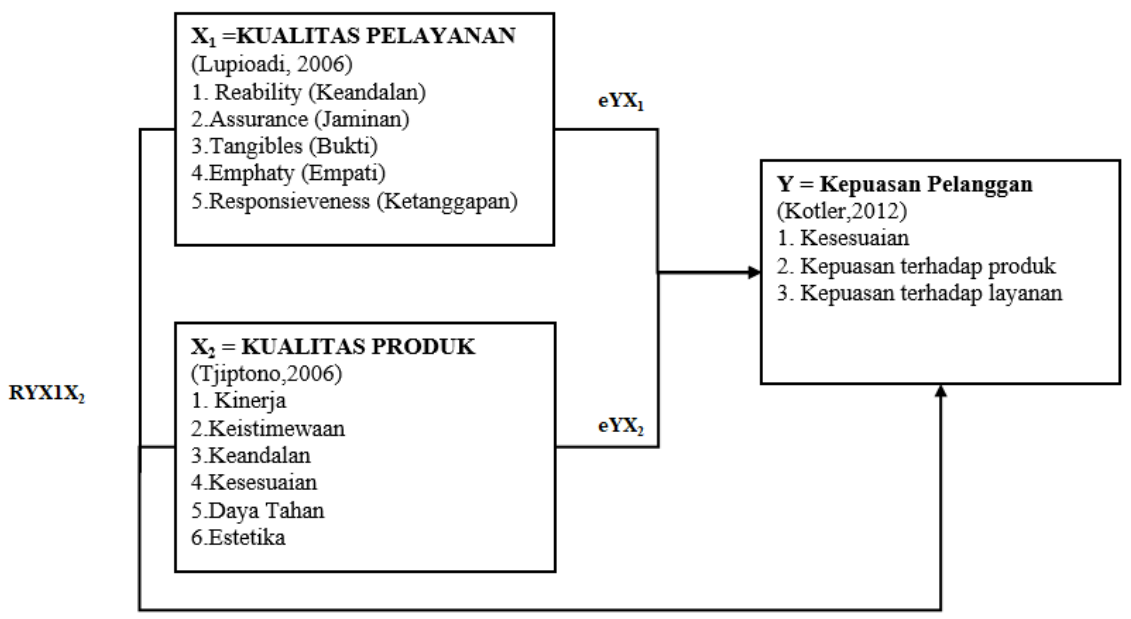

Gambar 1 Model Penelitian

Melihat paparan diatas didukung dari teori-teori para pakar terkait, maka hipotesis yang dapat disimpulkan sebagai berikut:

Ho1: Diduga Kualitas Pelayanan tidak terdapat pengaruh yang positif dan signifikan terhadap Kepuasan Pelanggan Perusahaan Leasing PT BCA Finance

Ha1: Diduga Kualitas Pelayanan terdapat pengaruh yang positif dan signifikan terhadap Kepuasan Pelanggan Perusahaan Leasing PT BCA Finance

Ho2: Diduga Kualitas Produk tidak terdapat pengaruh yang positif dan signifikan terhadap Kepuasan Pelanggan Perusahaan Leasing PT BCA Finance

Ha2: Diduga Kualitas Produk terdapat pengaruh yang positif dan signifikan terhadap Kepuasan Pelanggan Perusahaan Leasing PT BCA Finance

Ho3 : Diduga Kualitas Pelayanan dan Kualitas Produk tidak terdapat pengaruh yang positif dan signifikan terhadap Kepuasan Pelanggan Perusahaan Leasing PT BCA Finance

Ha3: Diduga Kualitas Pelayanan dan Kualitas Produk terdapat pengaruh yang positif dan signifikan terhadap Kepuasan Pelanggan Perusahaan Leasing PT BCA Finance

\section{Metode Penelitian}

Objek Penelitian ini adalah PT BCA Finance Jakarta berlokasi di Jalan Metro Pondok Indah No.10 Jakarta Selatan 12310 Indonesia. Dimana subyek teliti adalah yang melakukan transaksi di perusahaan tersebut selama kurun waktu tertentu. Untuk mengetahui kepuasan pelanggan yang dipengaruhi oleh kwalitas playanan dan produk. Penelitian ini akan dilaksanakan dalam waktu kurang lebih 3 (tiga) bulan sejak ditanda tanganinya kontrak perjanjian penelitian.

Metode yang digunakan untuk penelitian ini adalah metode kuantitatif. Metode kuantitatif digunakan untuk meneliti pada populasi atau sampel tertentu, teknik pengambilan sampel pada umumnya dilakukan secara random, pengumpulan data menggunakan instrumen penelitian, analisis data bersifat kuantitatif / statistik dengan tujuan untuk menguji hipotesis yang telah ditetapkan (Sugiyono, 2009: 13). Responden penelitian ini adalah seluruh nasabah di PT.BCA Finance sebanyak 130 orang nasabah.

\section{Hasil Penelitian dan Pembahasan}

\section{Hasil Analisa Data}

Proses analisa data dapat di peroleh gambaran hasil penelitian, pengolahan data responden dari instrumentasi penelitian berupa kuesioner dengan jumlah yang telah ditetapkan sebelumnya. Pengumpulan data di pastikan sesuai dengan kaidah dan persyaratan yang terpenuhi untuk dianalisa, serta di interpretasikan agar dapat menjadi solusi atas permasalahan yang ada. 


\section{Uji Validitas}

Tabel 3. Validitas Kualitas Pelayanan (X1)

\begin{tabular}{|c|c|c|c|}
\hline \multicolumn{4}{|c|}{ Variabel Kualitas Pelayanan } \\
\hline Pernyataan & r-Hitung & r-Tabel & Keputusan \\
\hline KualPly-1 & 0,516 & 0,172 & Valid \\
\hline KualPly-2 & 0,695 & 0,172 & Valid \\
\hline KualPly-3 & 0,486 & 0,172 & Valid \\
\hline KualPly-4 & 0,370 & 0,172 & Valid \\
\hline KualPly-5 & 0,617 & 0,172 & Valid \\
\hline KualPly-6 & 0,356 & 0,172 & Valid \\
\hline KualPly-7 & 0,221 & 0,172 & Valid \\
\hline KualPly-8 & 0,482 & 0,172 & Valid \\
\hline KualPly-9 & 0,430 & 0,172 & Valid \\
\hline KualPly-10 & 0,270 & 0,172 & Valid \\
\hline
\end{tabular}

Sumber: Pengolahan Data SPSS20

Tabel 4. Validitas Kualitas Produk (X2)

\begin{tabular}{|c|c|c|c|}
\hline \multicolumn{4}{|c|}{ Variabel Kualitas Produk } \\
\hline Pernyataan & r-Hitung & r-Tabel & Keputusan \\
\hline Kprod-1 & 0,311 & 0,172 & Valid \\
\hline Kprod-2 & 0,329 & 0,172 & Valid \\
\hline Kprod-3 & 0,512 & 0,172 & Valid \\
\hline Kprod-4 & 0,549 & 0,172 & Valid \\
\hline Kprod-5 & 0,388 & 0,172 & Valid \\
\hline Kprod-6 & 0,547 & 0,172 & Valid \\
\hline Kprod-7 & 0,447 & 0,172 & Valid \\
\hline Kprod-8 & 0,516 & 0,172 & Valid \\
\hline Kprod-9 & 0,510 & 0,172 & Valid \\
\hline Kprod-10 & 0,552 & 0,172 & Valid \\
\hline
\end{tabular}

Sumber: Pengolahan Data SPSS20

Tabel 5. Validitas Kepuasan Pelanggan (Y)

\begin{tabular}{|c|c|c|c|}
\hline \multicolumn{4}{|c|}{ Variabel Kepuasan Pelanggan } \\
\hline Pernyataan & r-Hitung & r-Tabel & Keputusan \\
\hline Kpel-1 & 0,506 & 0,172 & Valid \\
\hline Kpel-2 & 0,208 & 0,172 & Valid \\
\hline Kpel-3 & 0,512 & 0,172 & Valid \\
\hline Kpel-4 & 0,495 & 0,172 & Valid \\
\hline Kpel-5 & 0,487 & 0,172 & Valid \\
\hline Kpel-6 & 0,292 & 0,172 & Valid \\
\hline Kpel-7 & 0,319 & 0,172 & Valid \\
\hline Kpel-8 & 0,400 & 0,172 & Valid \\
\hline Kpel-9 & 0,495 & 0,172 & Valid \\
\hline Kpel-10 & 0,338 & 0,172 & Valid \\
\hline
\end{tabular}

Sumber: Pengolahan Data SPSS20

Melihat pada data tabel hasil uji validitas masing-masing variable di atas, variabel Kualitas Pelayanan (X1), Kualitas Produk(X2) dan KepuasanPelangan(Y) memperoleh nilai rhitung > rtabel (0.172), maka dari itu semua pernyaataan kuesioner dinyatakan valid dan karena nya kuesioner yang digunakan dikatakan layak sebagai instrumentasi penelitian. 


\section{Uji Reliabilitas}

Uji yang menentukan kehandalan suatu kuesioner dalam mengukur konsistensi jawaban responden setiap saat. Dibawah ini merupakan hasil dari pengujian Realibilitas dngan mnggunakan aplikasi SPSS20.

Tabel 6. Pengujiian Reliabilitas

\begin{tabular}{|l|c|c|c|}
\hline \multicolumn{1}{|c|}{ Variabel } & Nilai hitung Alpha Cronbach & N of Items & Keterangan \\
\hline Kualitas Pelayanan $\left(\mathrm{X}_{1}\right)$ & 0,678 & 10 & Reliabel \\
\hline Kualitas Produk $\left(\mathrm{X}_{2}\right)$ & 0,698 & 10 & Reliabel \\
\hline Kepuasan Pelanggan $(\mathrm{Y})$ & 0,658 & 10 & Reliabel \\
\hline
\end{tabular}

Sumber: Pengolahan data di SPSS20

Dapat kita perhatikan hasil pengujian diatas bahwa setiap variabel memiliki nilai alpha Cronbach melebihi batas aman reliabel $(0,6)$, jadi dapat dikatakan bahwa setiap point pernyataan kuisionner bersifat reliabel dan dapat digunakan waktu kewaktu.

\section{Uji Asumsi Klasik}

\section{Uji Normalitas Data}

Hasil uji Normalitas salah satunya data bisa dilihat melalui grafik P-Plot dibawah ini. Jika data distribute normal, penggambaran garis data akan mengikuti garis normal diagonal (Ghozali, 2010).

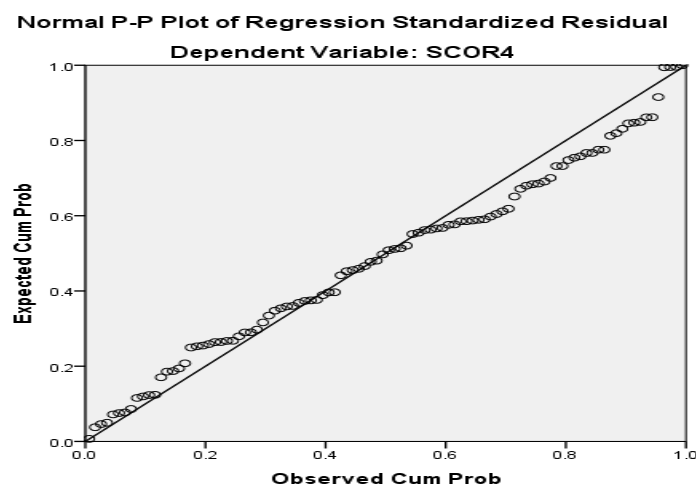

Gambar 2 Hasil Uji Normalitas Data

Hasil Pengujian memnuhi asumsi normalitas dapat dilihat titik-titik data tersebar disekitar wilayah garis diagonal.

\section{Multikoliniieritas}

Tabel 7. Pengujian Multi kolinieritas

\begin{tabular}{|l|c|c|c|c|c|}
\hline \multirow{2}{*}{ Variabel } & \multicolumn{4}{|c|}{ Collinearity Statistics } & \multirow{2}{*}{ Kesimpulan } \\
\cline { 2 - 5 } & Tollerance & Perhitungan & VIF & Perhitungan & terjadi \\
\hline Kualitas Pelayanan & 0,998 & $0,998 \geq 0,01$ & 1,01 & $1,013 \leq 10,0$ & $\begin{array}{l}\text { Tidak } \\
\text { Multikolinearitas }\end{array}$ \\
\hline Kualitas Produk & 0,991 & $0,991 \geq 0,01$ & 1 & $1,003 \leq 10,0$ & $\begin{array}{l}\text { Tidak terjadi } \\
\text { Multikolinearitas }\end{array}$ \\
\hline
\end{tabular}

Sumber: Pengolahan Data dengan SPSS20

Nilai VIF dari masing-masing variable tidak ada yang lebih dari 10 dan tidak ada yang memiliki tolerance value lebih kecil dari 0,1. Kesimpulan dalam penelitian ini bebas dari adanya multikolinearitas dan semua varable bebas yang dipakai dalam penelitian ini bebas dari gejala multikolinearitas. 


\section{Uji Regresi Linier Berganda}

Berikut dibawah ini merupakan persamaan regresi linier berganda, yang daripadanya dapat dilihat pengaruh variabel bebas yang adalah kualitas produk (X1), kualitas layanan (X2) terhadap variabel terikat nya yaitu keputusan pembelian $(\mathrm{Y})$

Tabel 8. Hasil Uji Regresi Linier Berganda

Coefficients $^{\mathrm{a}}$

\begin{tabular}{|c|c|c|c|c|c|c|}
\hline \multirow{2}{*}{\multicolumn{2}{|c|}{ Model }} & \multicolumn{2}{|c|}{$\begin{array}{c}\text { Unstandardized } \\
\text { Coefficients }\end{array}$} & \multirow{2}{*}{$\begin{array}{c}\begin{array}{c}\text { Standardized } \\
\text { Coefficients }\end{array} \\
\text { Beta } \\
\end{array}$} & \multirow[t]{2}{*}{$\mathrm{t}$} & \multirow[t]{2}{*}{ Sig. } \\
\hline & & B & Std. Error & & & \\
\hline 1 & (Constant) & 20.941 & 12.014 & & 7.448 & .000 \\
\hline \multirow{4}{*}{2} & SCOR1 & .520 & .092 & .547 & 5.652 & .000 \\
\hline & (constant) & 44.440 & 21.095 & & 10.607 & .000 \\
\hline & $\begin{array}{l}\text { SCOR1 } \\
\end{array}$ & .437 & .096 & .459 & 4.528 & .000 \\
\hline & SCOR2 & .350 & .100 & .356 & 3.494 & .001 \\
\hline
\end{tabular}

a. Dependent Variable: Kepuasan Pelanggan

Sumber: Pengolahan Data dengan SPSS20

Dari hasil regresi pada tabel diatas yang didapat maka dibuat persamaan regresi sebagai berikut: $\mathrm{Y}=44,440+0,437 \mathrm{X} 1+0,350 \mathrm{X} 2+\mathrm{e}$

Berdasarkan atas hasil koefisien diatas, dapat disimpulkan bahwa Kualitas Pelayanan $\left(\mathrm{X}_{1}\right)$ dan Kulitas Produk $\left(\mathrm{X}_{2}\right)$ bernilai positif terhadap Kepuasan Pelanggan. Diperoleh dari hasil penelitian bahwa nilai regresi untuk variabel Kualitas Pelayanan sebesar 0,437 dan kualitas produk sebesar 0,35, dengn nilai signifikansi 0,000 sehingga dapat dikatakan bahwa Kualitas Pelayanan $\left(\mathrm{X}_{1}\right)$ dan Kulitas Produk $\left(\mathrm{X}_{2}\right)$ berpengaruh positif dan signifikan terhadap Kepuasan pelanggan.

\section{Uji Koefisien Determinasi $\mathbf{R}^{2}$}

Pengujian ini berutjuan untuk menjelaskan seberapa besar pengaruh yang ditimbulkan oleh variabel bebas terhadap variabel terikatnya, pada tabel dibawah ini dapat dilihat nilai berdsasarkan kolom R Square.

Tabel 9. Hasil $\mathbf{R}^{2}$

Model Summary ${ }^{b}$

\begin{tabular}{|c|c|c|c|c|c|}
\hline Model & $\mathrm{R}$ & $\mathrm{R}$ Square & $\begin{array}{c}\text { Adjusted R } \\
\text { Square }\end{array}$ & $\begin{array}{c}\text { Std. Error of the } \\
\text { Estimate }\end{array}$ & $\begin{array}{c}\text { Durbin- } \\
\text { Watson }\end{array}$ \\
\hline 1 & $.661^{\mathrm{a}}$ & .437 & .420 & 1.950 & 1.508 \\
\hline
\end{tabular}

Predictors: (Constant) : Kualitas Pelayanan, Kualitas Produk

Dependent Variable: Kepuasan Pelanggan

Sumber: Pengolahan Data dengan SPSS20

Dari tabel diatas, dapat dijelaskan sebagai berikut:

Coefficient R sebesar 0.661. Artinya korelasi kualitas produk Keputusan Pembelian sebesar 0.393, yang berarti terdpat hubungan positif dengan nilai 0.661 antar variable Kualitas Pelayanan dan kualitas produk terhadap kepuasan pelanggan.

Coefficient Adjusted R Square bernilai 0.420, mengindikasikan bahwa kualitas pelayanan dan kualitas produk terhadàp Kepuasan Pelanggan berkontriibusi sebesar $42.0 \%$, sedangkan $58 \%$ sisanya djelaskan olehh variable lain diluar penelitian. 


\section{Uji Hipotesis}

\section{Uji Simultan (F)}

\section{Tabel 10. Hasil Uji F}

ANOVAa

\begin{tabular}{|c|l|r|r|r|r|c|}
\hline \multicolumn{2}{|l|}{ Model } & Sum of Squares & \multicolumn{1}{c|}{ df } & Mean Square & F & Sig. \\
\hline \multirow{3}{*}{1} & Regression & 283.684 & 3 & 94.561 & 24.855 & $.000^{\mathrm{b}}$ \\
\cline { 2 - 8 } & Residual & 365.226 & 96 & 3.804 & & \\
\cline { 2 - 8 } & Total & 648.910 & 99 & & & \\
\hline
\end{tabular}

Dependent Variable: Kepuasan Pelanggan

Predictors: (Constant) : Kualitas Pelayanan dan Kualitas Produk

Sumber: Pengolahan Data dengan SPSS20

Diatas dapat diperhatikan tabel Anova memperoleh hasil hitung Nilai F. Nilai df1 = k-1, dimana k merupakan jumlah variabel yang diteliti, sehingga df $1=4-1$ adalah 3 , dan df2 $=\mathrm{n}-\mathrm{k}$, dimana $n$ merupakan jumlah sampel dalam penelitian ini yaitu 130 . Sehingga df2 $=130-2$ adalah 128, maka penentuan nilai F tabel sebesar 2,68.

Perhitungan menunjukkan nilai $\mathrm{F}$ hitung 24.855, hal ini berarti $\mathrm{F}$ hitung lebih besar daripada $\mathrm{F}$ tabel, serta hasil nilai signifikansi 0,000 lebih besar daripada nilai signfikansi $5 \%$ $(0,05)$ yang artinya secara bersamaan, variable kwalitas pelayanan dan kwalitas produk mempengaruhi variable terikat yakni kepuasan pelanggan.

\section{Kesimpulan}

Kesimpulan hasil anilisis serta pembahasan yang telah dijelaskan sebelumnya, adalah sebagai berikut: (1). Kualitas Pelayanan berdasarkan 7(tujuh) indikator yang diinterpretasikan dengan 10 (sepuluh) butir pernyataan, diberikan kepada 130 orang responden, memiliki skor rata-rata 3.75, masuk dalam jajar nilai 3.41 - 4.20 dengan kategori Baik. Terlihat dari jawaban responden pada pernyataan "Petugas bank memiliki pengetahuan tentang produk yang mumpuni". (2). Kualitas produk 6 (enam) indikator yang diinterpretasikan dengan 10 (sepuluh) butir pernyataan, diberikan kepada 130 orang responden, memiliki skor rata-rata 3,8; masuk dalam jajar nilai 3.41 - 4.20 dengan kategori Baik. Terlihat dari jawaban responden pada pernyataan "Produk yang ditawarkan sesuai dengan kebutuhan saya". (3). Kepuasan Pelanggan dilihat dari 7 (tujuh) indikator yang diinterpretasikan lewat 10 (sepuluh) bulir pernyataan dalam kuesioner, lalu dibeirkan kepada 130 orang responden, meiliki skor ratarata 4,24; masuk dalam jajar nilai 4.20 - 5.00 yang artinya dalam kategori Sangàt Baik. Di dominasi oleh jawaban respondnen atas pernyataan "petugas bank memenuhi komitmen kepada pelanggan". (4). Seluruh variabel bebas berpengaruh positif dan signifikan terhadap variabel terikat yakni Kepuasan Pelanggan karena nilai signifikan yakni 0,001, <0,05 dan nilai F hitung (24.855) lebiih besar dariipada nilai F tabel (2.53).

\section{Ucapan terima kasih}

Ucapan terima kasih disampaikan kepada perusahaan yang menjadi objek penelitian dan semua pihak yang telah mendukung diselesaikannya penelitian ini.

\section{Daftar Pustaka}

Arikunto, Suharsimi. (2010). Prosedur Penelitian Suatu Pendekatan Praktek. PT. Rineka Cipta. Jakarta.

Buchari Alma. (2007). Manajemen Pemasaran dan Pemasaran Jasa, Alfabeta, Bandung

Fandy Tjiptono, (2008). Strategi Pemasaran. Yogyakarta: Andi.

Ghozali, Imam. (2005). Aplikasi Analisis Multivariate dengan Program SPSS", Semarang: BP Undip Semarang. 
Ariawan, Iwan, (1998). Besar dan Metode Sampel Pada Penelitian Kesehatan. Jurusan Biosatistik dan Kependudukan Fakultas Kesehatan Masyarakat Universitas Indonesia.

Andalusi, R. (2018). Pengaruh Kualitas Pelayanan, Harga, Dan Kualitas Produk Terhadap Kepuasan Pelanggan Instrumen Penunjang Laboratorium.Jurnal Madani: Ilmu Pengetahuan, Teknologi, Dan Humaniora, 1(2), 305-322. https://doi.org/10.33753/madani.v1i2.16

Azhari, (2001). Hubungan Antara Faktor Internal dan Faktor Eksternal Dengan Prestasi Belajar Siswa Di SPK Depkes Lubuk Linggau Tahun 2001. Tesis Program Pasca Sarjana Ilmu Kesehatan Masyarakat, Fakutas Kesehatan Masyarakat Universitas Indonesia, Depok.

Azwar, Saifuddin, (1998). Tes Prestasi Fungsi dan Pengembangan Pengukutan Prestasi balajar. Yogyakarta: Pustaka Pelajar Offset.

Chandra, Ardhian, (2016). Pengaruh Kualitas Pelayanan dan Bauran Pemasaran terhadap Loyalitas Pelanggan melalui Kepuasan Pelanggan dan Brand Loyality pada PT. Laborindo Sarana. Tesis Program Pasca Sarjana Ilmu Manajemen, Fakultas Ekonomi, Universitas Pancasila. Depok.

Depdikbud, (1994). Kamus Besar Bahasa Indonesia.Balai pustaka, Jakarta.

Deswarto, (2001). Hubungan Antara Motivasi Belajar Dan hasil Ujian Seleksi Masuk Dengan Prestasi Belajar Mahasiswa Di Akademi Keperawatan Departemen Keshatan Palembang Propinsi Sumatera Selatan Tahun 2001. Skripsi Program Sarjana Fakutas Kesehatan Masyarakat Universitas Indonesia, Depok.

Djamarah, Syaiful Bakri, (1994). Prestasi Belajar dan Kompetensi Guru. Usaha Nasional Surabaya

Endranto, Agung Jaya, (2001). Hubungan Antara Nilai Ujian Masuk FKM UI Dengan Indeks Prestasi Pada mahasiswa SKM Jalur B Angkatan tahun 1998 dan 1999/2000. Skripsi Program Sarjana Fakutas Kesehatan Masyarakat Universitas Indonesia, Depok.

Hidayat, Eka Putra Syarif. (2003). Hubungan Nilai Ujian Masuk Dan Motivasi Dengan Prestasi Belajar Mahasiswa Jurusan Teknik Radiodiagnostik Politeknik Kesehatan Jakarta II Departemen Keshatan Tahun 2003. Tesis Program Pasca Sarjana Ilmu Kesehatan Masyarakat, Fakutas Kesehatan Masyarakat Universitas Indonesia, Depok.

Irfanudin, A. (2019). Pengaruh Kualitas Produk, Harga Dan Kualitas Layanan Terhadap Kepuasann Pelanggan.Jurnal SeMaRaK: Jurnal Ilmiah Prodi Manajemen Universitas Pamulang, 2(1). http://dx.doi.org/10.32493/smk.v2i1.2662

Irfanudin, A., Andalusi, R., \& Jamil, I. (2020). Pengaruh Kualitas Produk Dan Promosi Terhadap Keputusan Pembelian Produk Pristine 8+ Pada PT Super Wahana Tehno.Jurnal SeMaRaK: Jurnal Ilmiah Prodi Manajemen Universitas Pamulang,3(3), 103-119. http://dx.doi.org/10.32493/smk.v3i3.7102.

Kotler, Philip dan Kevin Lane Keller, (2013). "Manajemen Pemasaran", Edisi 13, Jilid 2, Erlangga, Jakarta.

Kotler, Philip, \& Keller, Kevin L, (2009). "Manajemen Pemasaran", Edisi 13 jilid 1, Erlangga, Jakarta,

Kotler, Philip dan Amstrong, Gary, (2013), Principles of Marketing, 12th Edition, Jilid 1 Terjemahan Bob Sabran, Jakarta: Erlangga.

Rangkuti, Freddy. (2016). “Riset Pemasaran”. PT. Gramedia Pustaka Utama, Jakarta.

Lewis, Pamela S. Stephen H. Goodman, Patricia M. Fondt, (2004), Management; Challenges For Tomorrow's Leader", McGraw Hill.

Nasution, M.N, (2004), Manajemen Jasa Terpadu, PT. Ghalia Indonesia, Jakarta 
Rambat Lupiyoadi dan A. Hamdani, (2008), Manajemen Pemasaran Jasa, Salemba Empat, Jakarta

Riduwan, (2010), Metode dan Teknik Menyusun Tesis, Alfabeta Bandung

Sugiono, (2012), "Metode Penelitian Kuantitatif Kualitatif dan R\&D", Penerbit CV. Alfabeta. Bandung. 